\title{
Operational Risk, the Legal System and Governance Indicators: A Country- Level Analysis ${ }^{\#}$
}

\author{
IMAD MOOSA, LARRY LI AND TONY NAUGHTON* \\ SCHOOL OF ECONOMICS, FinANCE AND MARKETING \\ RMIT
}

\begin{abstract}
A total of 4388 operational loss events recorded over three decades in 57 countries are analyzed on a country level in terms of the size of the economy, the standard of living, the legal system, the regional factor and six governance indicators. The results show that the average severity of the operational losses incurred by firms located in a particular country are positively related to the size of the economy, measured by GDP, and the standard of living, measured by gross national income per capita. The results also show that loss severity is negatively related to governance indicators, particularly regulatory quality. The effect of governance indicators is explained in terms of their implications for corporate governance, hence internal controls, and their direct effect on criminal behaviour and the provision of discipline and deterrence.
\end{abstract}

EFMA Classification: 750,150

Keywords: Operational Risk, Operational Loss Events, Corporate Governance

\footnotetext{
\# The first author is grateful to the Australian Research Council for the Discovery Grant used to finance work on this project. We are also grateful for a research grant from the Australian Centre for Financial Studies.

* The corresponding author. Address: School of Economics, Finance and Marketing, RMIT, 445

Swanston Street, Melbourne, Victoria 3000, Australia. E-mail: tony.naughton@ rmit.edu.au.
} 


\section{Introduction}

Operational risk is the risk of (operational) losses resulting from the failure of people, processes, systems and from external factors. For a long time, operational risk was not even recognized. For example, Thirwell (2011) argues that while banks and other financial institutions are in the business of managing risk, that generally means managing credit risk, market risk, or insurance risk-the kinds of risk that are typically associated with banking and finance. Hence, his argument goes, financial institutions ignore the risks they have to manage if they wish to stay in business, "the stuff of operational risk". Dutta and Perry (2007) point out that "operational risk is being recognized as an important risk component for financial institutions as evinced by the large sums of capital that are allocated to mitigate this risk". Likewise, de Fontnouvelle (2007) argues that "the frequency of large operational losses, their widespread impact, and their reputational consequences highlight the importance of measuring, monitoring, and mitigating operational risk, as well as holding sufficient capital for unexpected losses". The importance of operational risk has therefore been recognize-it has come of age as a key component of the risk profile of not only financial institutions but firms in general.

The empirical literature on operational risk, particularly the determinants of operational losses, is rather thin, which is not surprising for at least two reasons. The first is the lack of good-quality data, given the secrecy with which firms treat their operational losses. The second is the difficulty of modelling operational risk because the causes of operational losses are extremely heterogeneous, ranging from fraud to fire and law suits. Operational risk is determined not only by firm-specific factors but also by macroeconomic factors and various aspects of the environment in which the 
firm operates. For these reasons, Chernobai et al. (2011) point out that "current academic research that sheds light on the determinants of operational risk is very limited".

The connection between operational risk, the rule of law and corporate governance has also been recognized. The definition of operational risk tells us that a major source of operational losses is people risk-that is the risk of incurring losses because of the failure of people in the sense of having criminal tendencies or because they are incompetent. Corporate governance pertains not only to people risk because a principal function of corporate governance is providing the framework whereby the management sets the procedural and behavioural rules that govern the structure and nature of operations. According to Vinella (2005), these rules cover "processes and the people, technology, procedures/rules, information, and infrastructure that implements them". This is typically followed by a review of the information pertaining to the overall operational performance as well as the degree of compliance with the rules. Corporate governance is clearly connected to operational risk, simply because it is a control function in the monitoring of operations. As for the rule of law, the connection with operational risk is conspicuous. ${ }^{1}$ The rule of law has direct implications for operational losses resulting from events such as fraud, copyright infringement, consumer protection and many others. It is also the case that the rule of law determines to a large extent the system of corporate governance. Therefore, both the rule of law and corporate governance have implications for the quality of controls within a firm, which has been recognized as a major determinant of operational risk (for example, Chernobai et al., 2011).

\footnotetext{
${ }^{1}$ The rule of law is determined by two factors: the legal system and the extent to which the law is enforced. See, for example, La Porta et al. (1998).
} 
Many high profile operational loss events have materialized as a result of a combination of the failure of people and processes/systems. In plain language, they have resulted from the actions of employees who committed fraud (hence the failure of people) in the absence of strict controls and monitoring systems (hence the failure of processes/systems). The failure of Barings Bank in 1995 was caused by this combination of failures. Likewise, Arnold et al. (2008) attribute the $\$ 7.2$ billion loss endured by Societe Generale in January 2008 (due to unauthorised trading) to moral hazard and the lack of internal controls. The lack of external controls (such as regulatory failure) has also been a contributory factor to some high-profile loss events. For example, the failure of the Securities and Exchange Commission (SEC) to act against Bernard Madoff allowed him to run a Ponzi scheme that cost investors in his hedge fund some $\$ 50$ billion. Madoff managed to do that not only because of the lack of regulatory oversight but also because of "fraudulent internal controls" (Chernobai et al., 2011).

Within the thin empirical literature on the determinants of operational risk, Chernobai et al. (2011) have conducted perhaps the most comprehensive and informative study that will certainly guide future research in this field. There are, however, studies dealing with operational losses resulting from fraud. For example, Brown et al. (2008) obtain operational risk information from SEC-mandated hedge fund disclosures and test the hypothesis that this information is redundant to hedge fund investors. Part of their analysis relates the operational risk of hedge funds (focusing more on fraudulent behavior) to observable fund characteristics, which is similar to the focus of 
Chernobai et al. on the relation between operational risk in financial institutions and observable firm characteristics.

The Chernobai et al. (2011) study explains operational risk in terms of firm-specific factors (including corporate governance), as well as factors reflecting the macroeconomic, financial and regulatory environments under which the underlying firms operate - the latter representing country-specific factors, which may also change over time within the same country. The firm-specific factors are taken to be the determinants of the quality of internal controls, which has direct implications for the incidence (both frequency and severity) of operational losses.

This study is the first of its kind, aiming to examine country-specific factors as determinants of operational risk. Firm-specific factors may exhibit cross-country differences, producing significant cross-country variation in the frequency, severity and distribution (among business lines, event types and corporate entity types) of operational losses, as revealed by Moosa and Li (2012b). Cross-country differences in operational risk may be attributed to cross-country differences in the factors that give rise to people risk, process risk, system risk and external risk. Moosa and Li (2012b) point out the following: (i) people risk depends on corporate governance, corruption, ethical standards, internal controls within firms, transparency and disclosure requirements, and management style; (ii) process risk depends, inter alia, on regulation, transparency and disclosure requirements, and legal issues such as copyrights and patents; (iii) system risk depends, inter alia, on the state of technology; and (iv) external risk is determined by the severity of economic fluctuations, regulation, disclosure requirements, compliance requirements, and environmental 
standards. They conclude that since these factors are likely to be different across countries, the distribution and incidence of operational losses differ as well.

Our objective here is to specify, estimate and test a model of operational risk that explains the severity of operational losses in terms of cross-country differences. For this purpose we use a sample of 4388 operational loss events recorded over three decades in 57 countries. Another difference from the Chernobai et al. (2011) study is that we aim to explain the severity of operational losses across countries, whereas they focus exclusively on the "factors that cause an operational risk event to occur", meaning the frequency of losses. They state explicitly their desire to "leave the severity of losses ... to future research". This is therefore our contribution to "future research".

To specify the model we must first examine the country-specific determinants of operational risk, which we envisage to be the following: size, standard of living, the legal system, the region to which the country belongs and governance indicators, which include, among others, the rule of law. Since no study of operational risk has been conducted on a country level, we justify the selection of these variables in part by extrapolating from firm-level studies. For example, instead of using firm-specific corporate governance variables, we use country-specific governance indicators as explanatory variables.

\section{Size and the Standard of Living as Determinants of Operational Risk}

In our model, size is measured by the underlying country's gross domestic product, while the standard of living is measured by gross national income per capita. We start 
by considering the effect of the standard of living, simply because no study has considered this factor as a determinant of operational risk in a particular country. The relation between operational risk and the standard of living is rather intuitive and can be easily extrapolated from the operational risk facing an individual. We would expect the operational loss incurred by a victim of mugging, for example, to be positively related to how rich the victim is (or was). Likewise, we would expect the loss incurred by a bank as a result of armed robbery to be bigger in rich countries (there would be more valuables in the safety deposit boxes than in a poor country). Hence we suggest the hypothesis that operational risk at a country level is positively related to the standard of living as measured by gross national income per capita.

Next we consider the proposition that big operational losses occur in countries with big economies, which may also sound intuitive. Research on the effect of size on operational risk has been confined to the underlying firm size, given that the basic indicators approach (BIA) for the measurement of regulatory capital against operational risk under Basel II is based on the assumption that operational losses are related to firm size. Under the BIA, regulatory capital against operational risk is measured as $15 \%$ of the average gross income over the previous three years. However, the empirical evidence on the relation between operational losses and firm size is far from conclusive.

The hypothesised relation between operational losses and firm size, which is explained by Murphy et al. (2004) in terms of economies of scale and reputational effects, has been examined repeatedly. De Fountnouvelle (2007) suggests that while filtering by size is not unreasonable, "it is also possible that size may not matter for severity 
modelling". However, he points out that "this wouldn't mean that size does not matter for capital". He also adds that "we do not have an underlying model of OR against which to judge whether this result is surprising". Jobst (2007) argues that relating operational risk exposure to business volume amounts to an incomplete explanation that engenders misleading conclusions about operational risk exposure and the associated capital charges.

Shih et al. (2000) examine the relation between operational losses and firm size and conclude that the weak relation between size and loss amount can be attributed to factors such as inherent differences in risk (based on the type of business), management competence (or lack thereof) and the quality of the internal control environment. This sentiment is shared by Aue and Kalkbrener (2007) who suggest "no significant relationship between the size of a bank and the severity of its losses". However, Wei (2007) finds some connection between size and the severity of losses, producing cross-sectional regression results showing a positive and statistically significant relation between the logarithm of losses and the logarithm of assets (implying that the relation is nonlinear).

Moosa and Silvapulle (2012) conducted a study of 54 operational loss events experienced by eight Australian banks during the period 1990-2007. Their results show that the announcement of operational losses has an adverse effect on the stock price and market value of the announcing bank and that no systematic relation is present between losses and bank characteristics such as size and leverage. Another study by Moosa and Li (2012a) provides an analysis of 163 operational loss events experienced by a variety of British firms over the period 1999-2008. The results 
indicate that loss severity does not depend on firm size and that the decline in market value relative to the loss amount is positively related to firm size. In a study of 701 loss events experienced by British and American banks, Moosa and Li (2012b) show that loss severity depends positively on the announcing bank's size and that the decline in market value relative to the loss amount is negatively related to size. They explain this finding in terms of the financial muscle of big banks, their ability to obtain funds and their ability to demand and obtain the too-big-to fail status.

Chernobai et al. (2011) use size as an explanatory variable for operational risk because the accounting literature reveals that small firms tend to have weaker internal controls, which means that smaller firms are more likely to experience operational losses than large firms. They find the coefficient on size to be highly significant for all event types, with a value close to 1 , indicating that the average events per month "roughly scales with the firm's market capitalization".

On a firm level, therefore, the evidence is mixed, which is to be expected given that it is possible to present plausible arguments for why we should expect bigger firms to endure more severe losses, and vice versa. On a country level, however, it is more plausible to envisage a positive rather than negative relation between the size of the economy and the operational losses endured by the firms operating in that economy. Operational risk is related to the value of transactions, which is bound to be greater in a big economy.

\section{The Legal System as a Determinant of Operational Risk}


In general commercial laws come from two traditions: common law, which is English in tradition, and civil law, which is derived from Roman law. Three commercial laws fall under the civil tradition: French, German and Scandinavian. According to La Porta et al. (1998), "the French and the German civil traditions, as well as the common-law tradition, have spread around the world through a combination of conquest, imperialism, outright borrowing, and more subtle imitation”.

La Porta et al. (1998) argue that "the difference in legal protections of investors might help explain why firms are financed and owned so differently in different countries". It is also plausible to suggest that operational risk occurs with different profiles in different countries, as demonstrated by Moosa and Li (2012b), in part because of differences in the legal systems. Theoretical studies of the costs and benefits of alternative legal rules governing investors right have been conducted by Grossman and Hart (1988), Harris and Raviv (1988), Gromb (1993), Bebchuk (1994), and Burkart and Lee (2007). The problem encountered by scholars dealing with this issue is that "there have been no systematic data available on what the legal rules pertaining to corporate governance are around the world, how well these rules are enforced in different countries, and what effect these rules have" (La Porta et al, 1998).

La Porta et al. (1998) conclude that it is not only the origin of the legal system but also the degree of law enforcement that creates cross-country differences. Their results show that (i) civil laws give investors weaker legal rights than common laws do, independent of the level of per capita income; ${ }^{2}$ (ii) common-law countries give both

\footnotetext{
${ }^{2}$ To find out if the legal system has implications for operational risk, per capita income-according to La Porta et al. (1998) — should be used as a control variable. This is another argument supporting the inclusion of the standard of living, measured in terms of per capita income, as an explanatory variable in our model.
} 
shareholders and creditors the strongest, and French-civil-law countries the weakest, protection; (iii) German civil law and Scandinavian countries generally fall between the other two; (iv) the quality of law enforcement is the highest in Scandinavian and German civil law countries, next highest in common-law countries, and lowest in French-law countries; and (v) poor protection on French civil-law countries is associated with extremely concentrated share ownership. Jensen and Meckling (1976) and Shleifer and Vinshy (1986) conclude that concentration of share ownership provides managers with incentives to work and large investors with incentive to monitor the managers. Shleifer and Vinshy (1997) argue that a very high ownership concentration may be a reflection of poor investor protection.

John et al. (2008) examine the relation between investor protection, which in part depends on the legal system, and risk choices in corporate investment. They suggest several reasons why a positive or negative association can be expected between investor protection and corporate risk taking. First, investor protection dampens the magnitude and importance of private benefits to management, curbing the tendency to adopt risky projects. Second, non-equity stakeholders, such as banks and regulators that often prefer conservative investment strategies, may exert influence that is higher when investor protection is low. Third, improvement in investor protection is associated with a reduction in dominant shareholders' presence, which leads to greater managerial discretion to implement conservative policies. Fourth, poor investor protection may be associated with the presence of a dominant owner who may instruct lower-layer units to take excess risk and channel gains to upper-layer units. The empirical results of John et al. reveal a significantly positive relation between investor protection and risk taking. While the risk referred to here sounds more like market risk 
and credit risk (financial risk in general), an element of operational risk is involved in both. ${ }^{3}$ However, a direct link to operational risk can be found in their reference to the private benefits accruing to managers, including "the corporate cash flows that they plan to divert to themselves". Diversion of corporate cash flows may involve fraud, hence operational losses.

Differences in legal systems are likely to have implications for cross-country differences in operational risk. The connection may be direct in as far as the legal system provides deterrence against offences and criminal behaviour, including bribery, forgery, fraud, insider trading, computer hacking, discrimination, and many more that fall under various categories of operational loss events. The connection may be indirect in the sense that the legal system has implications for corporate governance, which in turn has implications for internal control and operational risk management. However, we must bear in mind, once again, that what matters is not only the legal system but also the extent of law enforcement.

\section{Corporate Governance as a Determinant of Operational Risk}

Corporate governance may be defined formally as "procedures and processes according to which an organisation is directed and controlled" (OECD, 2005). The corporate governance structure specifies the distribution of rights and responsibilities among various stakeholders (such as the board, managers and shareholders) and lays down the rules and procedures for decision making. The discretionary power of managers is pivotal aspect corporate governance, and this is why Johnson et al. (2000)

\footnotetext{
${ }^{3}$ For example, trading in volatile markets presents exposure to market risk. If a trader gets tempted by initial gains to exceed the prescribed trading limits, operational risk will be present. Also, intense trading activity puts pressure on the back office, which gives rise to operational risk exposure in the form of potential human error.
} 
contend that "corporate governance simply means the effectiveness of legal mechanisms that prevent managers from stealing”. Thus, corporate governance also provides the structure through which corporate objectives are set, the means of attaining the objectives and procedures for monitoring performance.

Corporate governance systems are shaped by the underlying legal systems and cultural factors. La Porta et al. (1998) explain the connection between the legal system and corporate governance by suggesting that "legal systems matter for corporate governance" and that "firms have to adapt to the limitations of the legal system that they operate in". Anderson (2010) argues that "there is an enormous array of source material when considering the strength or otherwise of any given code of Corporate Governance" and that "local laws, customs and cultures dictate approaches to Corporate Governance and colour the manner in which it is received by boards of directors, investors and other stakeholders". John et al. (2008) examine the relation between investor protection (which is determined in part by the legal system) and risk taking, but they refer to the relation between "corporate governance and risk-taking" (this is actually the title of their paper). Investor protection and risk taking have implications for corporate governance and the quality of internal controls, hence exposure to operational risk.

By considering the description of corporate governance, the connection with operational risk becomes quite conspicuous. The failure of corporate governance has been suggested as an explanation for financial scandals and the global financial crisis. For example, Morrison (2004) argues that "there is a general consensus that the accounting scandals which arose in the early years of this century in the United States 
were evidence of failures of US corporate governance". Anderson (2010) argues that while corporate governance alone is not the cause of the global financial crisis, "corporate governance could have prevented some of the worst aspects of the crisis had effective governance operated throughout the period of time during which the problems were developing and before they crystallised". He adds that "effective corporate governance could have helped to reduce the catastrophic impacts that the global and national economies are now suffering". Human resources, asset management systems and procedures are fundamental tools that guide a firm to manage operational risk. These factors are underpinned by corporate governance principles and processes.

Laeven and Levine (2009) examine the proposition that risk taking varies with the comparative power of shareholders within the corporate governance structure of banks in a number of countries. Their study is an extension of the standard agency theory, which suggests that ownership structure influences corporate risk taking (for example, Jensen and Meckling, 1976). The results show that banks with more powerful owners tend to take greater risks, but the relation between ownership and risk weakens in the presence of shareholder protection laws. Again, while risk-taking in this sense pertains to financial risk, it involves significant components of operational risk.

Thirwell (2004) suggests that "without the culture and control embodied by good corporate governance in the Boardroom, there will be no effective Op Risk management". Indeed, some authors believe that corporate governance has implications for the risk management function at large. For example, Sapovadia (2008) argues that "good corporate governance practice provides a way to realize the 
vision of mitigating risks and optimizing performance simultaneously in today's competitive and regulatory environment".

Young (2006) analyzes the connection between corporate governance and operational risk by starting with a definition of operational risk, which goes as follows: "Operational risk is broadly defined as the exposure of an organization to potential losses resulting from shortcomings and/or failures in the execution of its operations". He attributes operational losses to "internal failures or shortcomings of people, processes, and systems, as well as the inability of people, processes, and systems to cope with the adverse effects of external events". He also suggests the following principles: (i) the organizational structure ensures that specific roles and responsibilities are allocated for effective operational risk management, which is a specific corporate governance requirement for risk management; (ii) policies and procedures are imperative for risk management in order to provide consistency and discipline within a firm and ensure the overall defining and allocating of specific roles and responsibilities for managing risk; (iii) internal controls should be established to ensure the effectiveness of policies and procedures, which is another good corporate governance requirement; and (iv) risk reporting is an important corporate governance requirement that assists in establishing an effective decision making process.

Controls breakdowns, which caused the huge operational losses endured by the likes of Barings Bank, Allied Irish Bank and Societe Generale, are related to the underlying corporate governance system. Examples of these breakdowns are the following: (i) lack of adequate management supervision and accountability and failure to develop a strong risk management culture within the firm; (ii) inadequate assessment of the risk 
of certain activities; (iii) the absence or failure of key control activities, such as segregation of duties, approvals, verifications, reconciliations, and reviews of operating performance; (iv) inadequate communication of information between levels of management within the firm, particularly in the upward communication of problems; and (v) inadequate or ineffective audit programs and other monitoring activities. These control breakdowns are typically issues that a well-structured corporate governance and risk management framework addresses.

If corporate governance is a determinant of internal controls, it must be related to operational risk. Chernobai et al. (2011) draw extensively from the accounting literature in selecting firm-specific explanatory variables for operational risk because the accounting literature has revealed several firm characteristics that are associated with weak internal controls over financial reporting (for example, Ashbaugh-Skaife et al., 2007; Doyle et al., 2007; Elbannan, 2009). Although the accounting literature is about financial reporting, Chernobai et al. argue that the same variables are also relevant to operational risk. Another set of explanatory variables are identified by the accounting literature on earnings manipulation and accounting restatements, which highlight the role of board characteristics (for example, Dechow et al., 1996; Burns and Kedia, 2006; Efendi et al., 2007). Chernobai et al. include, as determinants of operational risk, measures of internal and external governance "since misreporting may indicate a lack of control", which is "consistent with the role of senior management oversight and accountability in enforcing risk management controls".

The importance of internal controls, driven by the quality of corporate governance, is highlighted by the Basel Committee (BCBS, 1998) in a survey the operational risk 
management practices of 30 major banks. The survey revealed strong and consistent emphasis on the importance of management oversight and business line accountability for operational risk. The respondents to the survey thought that senior management commitment was critical for successful firm-wide risk management. The participating banks reported that high-level oversight of operational risk is performed by its board of directors, management committees or audit committee. In addition, most respondents referred to the important role of an internal monitor or "watchdog," such as a risk manager or risk committee, product review committee, or audit committee. However, the survey revealed that the assignment of formal responsibilities for operational risk measurement and monitoring is far from universal, with only about half of the participating banks having such a manager in place. These factors of course are bound to be divergent across countries. While Basel II and Basel III require (under Pillar 2) senior management and the board of directors to play an active role in operational risk management, the absence of uniform implementation of the Basel accords across countries gives rise to cross-country differences in operational risk management practices (and hence differences in operational losses).

Chernobai et al. (2011) distinguish between internal corporate governance (as measured by board characteristics) and external corporate governance, arguing that while the relation between internal corporate governance and internal controls is intuitive, external corporate governance could play a role. On external corporate governance, Bertrand and Mullainathan (2003) show that, when shielded from an open market for corporate control, managers are reluctant to perform cognitively difficult tasks such as closing old plants, opening new plants, or bargaining with suppliers and labor unions. Elbannan (2009) finds that firms with more anti-takeover provisions, as 
proxied by the Gompers et al. (2003) G-index, are more likely to suffer from weakness in internal controls. ${ }^{4}$

Another group of variables that Chernobai et al. (2011) relate to operational risk pertains to CEO incentives. This is because the structure of executive compensation is likely to be relevant to a firm's internal control environment. For example, a strong equity incentive might cause management to focus too much on beating earnings forecasts or stock price targets, while giving short shrift to risk management controls. Studies by Burns and Kedia (2006) and Efendi et al. (2007) provide evidence indicating that the likelihood of financial misreporting is positively related to CEO incentives, such as the size and stock price sensitivity of executive stock option holdings. Regardless of how one measures the importance of CEO compensation components, the factors contributing to more frequent financial misreporting should give rise to a corporate environment that tolerates fraudulent behavior, excessive risk taking and loose internal control, resulting in operational loss events of the types defined by the Basel Committee (see appendix).

The specific corporate governance variables used by Chernobai et al. (2011) include broad characteristics such as the number of board members and the number of board meetings in a year. A larger number of board members and board meetings could mean that more effort and resources are devoted to improving internal control, but they could also be proxies for the complexity of the firm. Again, these characteristics differ across countries, more so than within one country.

\footnotetext{
${ }^{4}$ A higher $\mathrm{G}$ index means that the firm has a larger number of anti-takeover provisions. This is typically taken to be an indicator of weaker external governance, which is positively related to operational risk.
} 


\section{Regional Factors as a Determinant of Operational Risk}

The regional factors included in our model are designed to capture cross-country differences that cannot be captured explicitly because of the unavailability of data. Moosa and Li (2012b) examine the proposition that cross-country differences in the factors determining the frequency and severity of operational losses lead to crosscountry differences in the distribution and incidence of operational loss events in terms of frequency and severity. For this purpose they consider more than four thousand operational loss events covering eleven countries or country groups. The results reveal differences with respect to the type of loss events prevailing in each country or country group as well as differences with respect to the dominance of events of certain type in a particular business line and corporate entity type. Eleven countries and country groups are considered: Africa, Canada, China, East Asia, Europe, Middle East, Oceania, Latin America, U.K. and U.S. The decision to consider a country on its own or as part of a country group depends on the number of operational loss events reported for each country. This classification is also used in this study.

We have argued that the factors affecting corporate governance and internal controls are likely to differ across countries. The other factors and explanatory variables used by Chernobai et al. (2011) exhibit significant cross-country variation. One of these variables is the structure of CEO compensation (bonus relative to salary). Another is firm age because younger firms are expected to have higher operational risk (they could still be in the process of developing internal control procedures). Complexity is another factor-intuitively more complex firms are expected to have higher operational risk because they are more difficult to control and monitor. Also 
intuitively, we expect to find more complex firms in the developed world than in emerging countries. Other factors that exhibit cross-country variation account for the general macroeconomic and financial environment as well as regulatory changes. ${ }^{5}$

\section{Model Specification}

The previous discussion of the determinants of operational risk suggests that a (crosssectional) country-level model of operational risk, whereby operational losses are explained in terms of country-specific characteristics may be written as follows:

$$
\operatorname{LOSS}_{i}=\alpha+\beta G D P_{i}+\gamma G N I_{i}+\sum_{j=1}^{6} \phi_{i j} G O V_{i j}+\sum_{j=1}^{3} \delta_{i j} L E S_{i j}+\sum_{j=1}^{10} \lambda_{i j} R E G_{i j}+\varepsilon_{i}
$$

The dependent variable in the model is LOSS, which is the average loss amount incurred by firms located in country $i$ over the sample period. The average loss amount (or average severity) is calculated as the ratio of total severity (total loss amount) to frequency (the number of loss events). This variable is measured in logarithmic terms in line with conventional practice.

The explanatory variables may be classified into two groups: those that are identified explicitly as country-specific variables and those that are not, hence they are proxied by dummy variables. The explicit explanatory variables are gross domestic product $(G D P)$, gross national income per capita $(G N I)$ and governance indicators $(G O V)$. Like LOSS, GDP and GNI are measured in logarithmic terms.

\footnotetext{
${ }^{5}$ Like most aspects of operational risk analysis, views are divergent on the effects of macroeconomic factors. Some would argue that more losses are incurred in a recession because of the possibility of law suits resulting from redundancy and because firms reduce their spending on everything, including internal controls. On the other hand it is arguable that the incidence of credit card fraud is higher during booms than in recessions, which makes operational losses procyclical rather than countercyclical. See, for example, Moosa (2011).
} 
We must emphasise that the list of explanatory variables appearing on the right-handside of equation (1) does not constitute a full list of the determinants of operational risk. Because of the heterogeneity of operational risk, finding a full list of the determining factors is a monumental task. Perhaps the closest thing to a full list is that presented by Chernobai et al. (2011). For example, de Fountnouville (2007) suggests that operational risk varies depending on firm size, geography, corporate structure, business line, the control environment, time, and macroeconomic and market variables. He also argues that "the observed loss distribution does vary by size" and that "it is not easy to disentangle variation in true loss severity from variation in reporting bias".

The variables that cannot be identified explicitly but are likely to cause cross-country differences in the severity of operational losses are captured by the dummy variables are the legal system $(L E S)$ and the geographical region $(R E G)$. In our model $L E S_{1}$ represents the English system, $L E S_{2}$ is the German system, while $L E S_{3}$ is the Scandinavian system, all measured relative to the French system. The reason why a dummy representing the French system does not appear explicitly is that La Porta et al. (1998) have shown that "common law countries generally have the strongest, and French-civil-law the weakest, legal protection of investors, with German- and Scandinavian-civil-law countries located in the middle". Therefore we are measuring the effect of each legal system relative to the French system. Likewise $R E G_{j}$ is a dummy variable representing region $j$ where $j=1,2, \ldots 10$. We use the same regional classification of Moosa and Li (2012b) such that 1 is Africa and so on. These dummy variables are measured relative to the U.S. 
Six governance indicators are considered-these are arguably the country-level equivalent of the firm-level corporate governance and internal control variables. The indicators are (i) voice of accountability (VOA), (ii) political stability (POS), (iii) government efficiency (GOE), (iv) regulatory quality (REQ), (v) the rule of law $(R O L)$, and (vi) control of corruption $(C O C)$. These composite indicators are prepared by the World Bank for over 200 countries from data on broad dimensions of governance (Kaufmann et al., 2010). ${ }^{6}$

Governance indicators are related to (or they are determinants of) operational risk because they include law and order and other measures of deterrence against crime and corruption (or lack thereof) as well as measures of regulatory quality. Laeven and Levine (2009) examine the impact on risk taking of interaction between one of these factors, regulatory quality, and corporate governance. They argue that the effectiveness of regulation on bank risk depends on the bank's ownership structure in such a way that regulation may have a positive or negative effect on risk taking.

It is typically implied that the characteristics measured by these indices are more pronounced in developed than in developing countries. For example, developing countries are often portrayed as needing financial regulation, prudential supervision, governance, anti-corruption measures and legal reform (for example, Rodrik, 2001). However, it should not be assumed that these indicators are always better for developed countries than for developing countries. ${ }^{7}$

\footnotetext{
${ }^{6}$ The updated data for the six indicators, together with the underlying sources are available on www.govindicators.org.

${ }^{7}$ For example, it is often argued that some developing countries have tighter and more effective banking regulation than developed countries. Acharya (2010) argues that "India should resist the call for a blind adherence to Basel III and persist with its asset-level leverage restrictions and dynamic sector risk-weight adjustment approach". The Economist (2011) agrees with the view expressed by
} 
Governance indicators are calculated from data on perceptions of governance from a wide variety of sources, which are organized into six clusters. For each of these clusters the unobserved components model is used to (i) standardize the data from these very diverse sources into comparable units, (ii) construct an aggregate indicator of governance as a weighted average of the underlying source variables, and (iii) construct margins of error that reflect the unavoidable imprecision in measuring governance. It is noteworthy that these governance indicators are measured in a way that corresponds to the definition of governance as "the manner in which power is exercised in the management of a country's economic and social resources for development" (Kaufmann et al., 2010). Table 1 presents definitions of the governance indicators and examples of the operational loss events related to each indicator. The Appendix exhibits a complete taxonomy of operational loss events as suggested by the Basel Committee.

\section{A Preliminary Examination of the Data}

Data on the operational losses endured by firms across all sectors worldwide were obtained from the Fitch (First) qualitative database, which contains long write-ups and useful information about loss events obtained from multiple sources. This database provides a comprehensive analysis of the circumstances under which loss events occur, but no supplementary data on the underlying firms are provided. The focus of the qualitative databases of operational losses is not on capturing every event that takes place but rather to examine events that are of greater relevance and interest to

Acharya, arguing that it is not clear why banks in third world countries should be regulated by Basel III when in fact they have tighter (and more effective) controls. Some crimes are punished more severely in developing than developed countries, hence the rule of law and law enforcement are more effective in this sense. 
subscribers. The data sample comprises 4388 loss events going back to 1975 and covering 57 countries that are classified under 11 single or country groups. As a rule of thumb, a country is considered on its own if it had a record of at least 75 events. Like the data on governance indicators, data on GDP and GNI were obtained from the World Bank.

Figure 1 exhibits average loss severity (the dependent variable in our model) for the 57 countries in our sample, divided into four quartiles based on loss severity. As we can see from Figure 1, countries do not seem to be organized predominantly by GDP, GNI, region, or legal system. This is because loss severity is determined by more than one factor in the absence of any dominant factor. Figure 2 shows the average loss severity corresponding to each event type. Apart from "other", internal fraud produces bigger losses, on average, than any other loss event. ${ }^{8}$

Table 2 is a correlation matrix of the governance indicators. As we can see, these indicators are highly correlated, which is intuitive. For example, we should expect the rule of law and the control of corruption to be highly correlated. The implication of high correlation is potential multicollinearity, which means that equation (1) cannot be estimated as it is. This issue will be addressed below.

\section{Empirical Results}

Owing to the potential multicollinearity problem, we start by estimating a version of the model represented by equation (1) that contains an average of the six governance variables, $A G O V$. This version of the model is written as

\footnotetext{
${ }^{8}$ Classified under "other" is any loss event that cannot be classified under any of the Basel Committee's loss events as exhibited in the appendix. One has to remember that the Basel classification pertains to banks only, whereas the loss events examined in this study cover corporate entities of various kinds.
} 


$$
L O S S_{i}=\alpha+\beta G D P_{i}+\gamma G N I_{i}+\phi_{i} A G O V_{i}+\sum_{j=1}^{3} \delta_{i j} L E S_{i j}+\sum_{j=1}^{10} \lambda_{i j} R E G_{i j}+\varepsilon_{i}
$$

When the model is estimated by OLS, we obtain the results reported in Table 3. The results show that the coefficients on GDP and GNI are significantly positive, as expected, and that the coefficient on the average governance variable is significantly negative, again as expected. This means that more severe operational losses are incurred in countries that have larger economies, higher standards of living and lower governance indicators. However, none of the dummies for the region and the legal system are statistically significant. It is possible that the legal system appears as if it does not matter (whether it is English, French, German or Scandinavian) because what matters more is the degree of law enforcement, which we would expect to be lower in small economies with low standards of living.

The role played by the nature (or origin) of the legal system may be distorted by the absence of data on law enforcement as argued by La Porta et al. (1998). It could also be that the effect of the legal system is captured by a particular governance indicator, the rule of law, which is embodied in the composite indicator $A G O V$. The same applies to the regional dummies, as the effect may be captured by the three variables, $G D P, G N I$ and $A G O V$. Furthermore, the regions were selected on the basis of the availability of data, hence China is in a group of its own because more than 75 loss events are recorded for China but the other South East Asian countries are lumped together because a smaller number of loss events are recorded for these countries. Moosa and Li (2012b) suggest that this may conceal the importance of regional dummies if the regional factor makes a difference for the distribution of loss events among event types and business lines, but not for the severity of losses. 
Having examined the results presented in Table 3, we conduct a variable deletion test on equation (2) by imposing the restrictions $\delta_{j}=0$ for $j=1,2,3$ and $\lambda_{j}=0$ for $j=1,2, \ldots 10$ separately and jointly. This is basically a Wald test of coefficient restrictions where the test statistic has an F distribution with a number of degrees of freedom that is determined in part by the number of restrictions. The test statistics are calculated from the residual sums of squares of the unrestricted model (2) and the following restricted models:

$$
\begin{aligned}
& \operatorname{LOSS}_{i}=\alpha+\beta G D P_{i}+\gamma G N I_{i}+\phi_{i} A G O V_{i}+\sum_{j=1}^{10} \lambda_{i j} R E G_{i j}+\varepsilon_{i} \\
& \operatorname{LOSS}_{i}=\alpha+\beta G D P_{i}+\gamma G N I_{i}+\phi_{i} A G O V_{i}+\sum_{j=1}^{3} \delta_{i j} L O R_{i j}+\varepsilon_{i} \\
& \operatorname{LOSS}_{i}=\alpha+\beta G D P_{i}+\gamma G N I_{i}+\phi_{i} A G O V_{i}+\varepsilon_{i}
\end{aligned}
$$

The results of the variable deletion test are presented in Table 4, which shows that none of the test statistics is significant, hence none of the restrictions can be rejected. We will therefore proceed by examining equation (5) further.

To start with, we estimate equation (5) for the six governance indicators because using the average may conceal the fact that some indicators are more important than others. The estimation results are presented in Table 5 for the six individual indicators (the $t$ statistics are reported in parentheses). The results show that the coefficients on the individual governance indicators are significantly negative except for POS. Explanations may be suggested as to why political stability turns out to be an insignificant determinant of operational losses. The first is that, as Table 1 shows, POS is related predominantly to events classified under damage to physical assets (DPA). 
For some reason, the database does not classify any of the loss events under DPA. ${ }^{9}$

The second explanation is that the majority of events in terms of both frequency and severity are recorded in a small number of countries, typically with high $P O S$ scores (most notably the U.S. and the U.K.). Hence sampling bias may explain this result.

In terms of significance and goodness of fit, the variable $R E Q$ seems to perform better than any of the others. To confirm this finding we conduct non-nested model selection tests, using two benchmarks: the model containing POS and the model containing $R E Q$. When $P O S$ is the benchmark, we specify M1 as follows:

$$
\operatorname{LOSS}_{i}=\alpha+\beta G D P_{i}+\gamma G N I_{i}+\phi_{i} P O S_{i}+\varepsilon_{i}
$$

If we test M1 against M2 that contains $V O A$ as the governance indicator, M2 can be written as follows:

$$
\operatorname{LOSS}_{i}=\alpha+\beta G D P_{i}+\not G N I_{i}+\phi_{i} V O A_{i}+\varepsilon_{i}
$$

and so on. Likewise, if the benchmark is $R E Q$, then $\mathrm{M} 1$ is written as

$$
\operatorname{LOSS}_{i}=\alpha+\beta G D P_{i}+\gamma G N I_{i}+\phi_{i} R E Q_{i}+\varepsilon_{i}
$$

The models M1 and M2 are said to be non-nested if the regressors of either of them cannot be expressed as an exact linear combination of the regressors of the other. Obviously M1 and M2, as represented by equations (6) and (7) or (8) and (7) are nonnested because they contain different governance indicators as explanatory variables.

\footnotetext{
${ }^{9}$ Some events that sound like damage to physical assets are classified under other categories (see appendix). For example, "malicious destruction of assets" is classified under internal fraud. Utility disruption, which is classified under BDSF, may be caused by damage to physical assets. Armed robbery, which is classified under external fraud, typically involves the destruction of assets. It is a fact that the Basel classification system of classification is not perfect and contains significant overlapping (for example, insider trading not on firm's account is classified under internal fraud, but insider trading on firm's account is classified under business disruption and system failure, BDSF).
} 
Six model selection tests are used: $N$ is the Cox test derived in Pesaran (1974); $N T$ is the adjusted Cox test derived in Godfrey and Pesaran (1983); $W$ is the Wald-type test proposed by Godfrey and Pesaran (1983); $J$ is the Davidson and MacKinnon (1981) test; $J A$ is the Fisher-McAleer (1981) test; and EN is the encompassing test proposed, inter alia, by Mizon and Richard (1986). All of the test statistics have t distributions, except for the encompassing test that has an F distribution. The tests are run both ways by testing M1 versus M2 and M2 versus M1. When M1 is tested versus M2, the null hypothesis is that M1 is a better model (in terms of specification) than M2. A significant test statistic indicates that M1 is not a better model than M2. When M2 is tested against M1, the null is that M2 is a better model than M1. A significant test statistic indicates that M2 is not a better model than M1. If we obtain significant test statistics both ways, this means that the two models are misspecified. If we get insignificant test statistics by testing M1 versus M2 and significant statistics by testing M2 versus M1, this means that M1 is preferred to M2. The econometrics of nonnested model selection tests can be found in Pesaran and Pesaran (1997).

The results of non-nested model selection tests are presented in Table 6. When the benchmark is the model containing POS as the governance indicator (equation 6), M1 is rejected against M2 but M2 is not rejected against M1. This tells us that POS, as an explanatory variable, is worse than any of the other governance indicators. Conversely, when the benchmark is the model containing $R E Q, \mathrm{M} 1$ is not rejected against $\mathrm{M} 2$ while $\mathrm{M} 2$ is rejected against $\mathrm{M} 1$, implying that, $R E Q$ is better as an explanatory variable than any of the other governance indicators. This means that the regulatory environment is more important for the control of operational risk than the rule of law and the control of corruption. A simple explanation for this finding is that 
the rule of law and control of corruption pertain primarily to people risk, the risk of incurring losses because of fraud whereas regulation covers a wide range of operational loss events. And even within people risk, the rule of law and control of corruption cannot deal with employee incompetence, because no criminal offence is committed if incompetence results in losses. ${ }^{10}$

The last thing to examine is a model that contains dummy variables for loss event types. The model may be specified as

$$
L O S S_{i}=\alpha+\beta G D P_{i}+\gamma G N I_{i}+\phi_{i} G O V_{i}+\sum_{j=1}^{6} L O E_{i j}+\varepsilon_{i}
$$

where $L O E_{j}$ is a dummy variable assuming the value of 1 for loss event $j$ and zero otherwise for $j=1, \ldots 6$. In this case $L O E_{1}$ represents BDSF, $L O E_{2}$ represents CPBP, $L O E_{3}$ represents EDPM, $L O E_{4}$ represents EPWS, $L O E_{5}$ represents EF and $L O E_{6}$ represents $\mathrm{IF}^{11}$ A significant dummy variable implies that a higher loss amount is typically associated with the corresponding loss event. The results of estimating equation (9) are presented in Table 7. The only dummy variable that is consistently significant is $\mathrm{LOE}_{6}$, which represents internal fraud. This result shows that the difference between the losses incurred as a result of internal fraud and other event types (as exhibited in Figure 2) is statistically significant.

\section{Conclusion}

In this study we conduct a country level analysis of a total of 4388 operational loss events of various types recorded over three decades in 57 countries. We estimate and test a model in which the average severity of losses incurred by firms located in each

\footnotetext{
${ }^{10}$ However, it can be argued that people may be prosecuted for criminal negligence.

${ }^{11}$ See the appendix for what the abbreviations stand for and the definitions of loss events.
} 
country is a function of the size of the economy, the standard of living, the legal system, the regional factor and six governance indicators. The results show that average severity is positively related to the size of the economy, measured by GDP, and the standard of living, measured by gross national income per capita.

The results also show that loss severity is negatively related to different governance indicators, particularly regulatory quality. The importance of governance indicators stems from their implications for corporate governance, which in part determines the quality of internal controls within a firm, as well as their direct effect on criminal behaviour and the provision of discipline. Out of the six governance indicators, regulatory quality turns out to be the most important in terms of explanatory power. This is likely because regulation pertains to all aspects of operational risk, unlike for example law and order which pertains mostly to crime and corruption (hence mostly related to internal and external fraud).

It is important, however, to mention that by "regulation" we do not mean the Baselstyle regulation of operational risk, but rather the overall regulatory set-up, including environmental regulation. This result actually sheds light on the debate on the pros and cons of environmental regulation as it is unclear whether or not environmental regulation pays off in terms of costs and benefits. Non-compliance with environmental regulation rules may produce huge penalties (hence operational losses), but a large body of the literature says that environmental regulation has positive net effects. Our results show that regulation, including environmental regulation, has a positive effect in the sense that high quality regulation reduces operational losses. 
Appendix: Operational Loss Events According to the BCBS Classification

\begin{tabular}{|c|c|c|}
\hline Event & BCBS Definition & Sub-categories/Examples \\
\hline Internal fraud (IF) & $\begin{array}{l}\text { Losses due to acts of fraud involving } \\
\text { at least one internal party. }\end{array}$ & $\begin{array}{l}\text { Account take-over and impersonation, bribes } \\
\text { and kickbacks, forgery, credit fraud, Insider } \\
\text { trading (not on firm's account), malicious } \\
\text { destruction and misappropriation of assets, tax } \\
\text { noncompliance, theft, extortion, embezzlement, } \\
\text { robbery, intentional mismarking of position, } \\
\text { unauthorised and unreported transactions }\end{array}$ \\
\hline External fraud (EF) & $\begin{array}{l}\text { Same as internal fraud except that it } \\
\text { is carried out by an external party. }\end{array}$ & $\begin{array}{l}\text { Computer hacking, theft of information, } \\
\text { forgery, theft }\end{array}$ \\
\hline $\begin{array}{l}\text { Employment practices } \\
\text { and workplace safety } \\
\text { (EPWS) }\end{array}$ & $\begin{array}{l}\text { Losses arising from violations of } \\
\text { employment and health and safety } \\
\text { laws. }\end{array}$ & $\begin{array}{l}\text { Discrimination, compensation and termination } \\
\text { issues, health and safety issues, general liability }\end{array}$ \\
\hline $\begin{array}{l}\text { Clients, products and } \\
\text { business practices } \\
\text { (CPBP) }\end{array}$ & $\begin{array}{l}\text { Losses arising from failure to meet } \\
\text { obligations to clients or from the } \\
\text { design of a product. }\end{array}$ & $\begin{array}{l}\text { Disputes over advisory services, violation of } \\
\text { anti-monopoly rules and regulations, improper } \\
\text { trade, Insider trading on firm's account, market } \\
\text { manipulation, money laundering, unlicensed } \\
\text { activity, product defects, exceeding client } \\
\text { exposure limits, account churning, aggressive } \\
\text { sales, breach of privacy, misuse of confidential } \\
\text { information, customer discloser violations }\end{array}$ \\
\hline $\begin{array}{l}\text { Damage to physical } \\
\text { assets (DPA) }\end{array}$ & $\begin{array}{l}\text { Losses arising from damage inflicted } \\
\text { on physical assets by natural } \\
\text { disasters and other events. }\end{array}$ & Terrorism, vandalism, natural disasters \\
\hline $\begin{array}{l}\text { Business disruption } \\
\text { and system failures } \\
\text { (BDSF) }\end{array}$ & $\begin{array}{l}\text { Losses arising from disruptions to or } \\
\text { failures in systems, } \\
\text { telecommunication and utilities. }\end{array}$ & $\begin{array}{l}\text { Hardware, software, telecommunications, } \\
\text { utility outage, utility disruption }\end{array}$ \\
\hline $\begin{array}{l}\text { Execution, delivery } \\
\text { and process } \\
\text { management (EDPM) }\end{array}$ & $\begin{array}{l}\text { Losses arising from failed } \\
\text { transaction processing with } \\
\text { counterparties such as vendors }\end{array}$ & $\begin{array}{l}\text { Incorrect client records, negligent loss or } \\
\text { damage of client assets, unapproved access to } \\
\text { accounts, client permissions, missing and } \\
\text { incomplete legal documents, failed mandatory } \\
\text { reporting obligations, inaccurate external } \\
\text { reports, non-client counterparty disputes, } \\
\text { accounting errors, collateral management } \\
\text { failure, data entry, maintenance or loading } \\
\text { error, delivery failure, miscommunication, } \\
\text { missed deadlines, vendor disputes }\end{array}$ \\
\hline
\end{tabular}

Source: BCBS (2004), Moosa (2007). 


\section{References}

Acharya, V.V. (2010) The Dodd-Frank Act and Basel III: Intentions, Unintended Consequences, Transition Risks, and Lessons for India. http://w4.stern.nyu.edu /blogs/riskintelligence/Dodd-Frank-Basel-and-India-by-Viral-Acharya.pdf.

Anderson, R. (2010) Risk Management and Corporate Governance. www.oecd.org/ dataoecd/29/4/42670210.pdf.

Arnold, M., Larsen, P.T., Hollinger, P., O’Doherty, J. and Milne, R. (2008) How Kerviel Exposed Lax Controls at Societe Generale, Financial Times, 7 February.

Ashbaugh-Skaife, H., Collins, D.W. and Kinney, W.R. (2007) The Discovery and Reporting of Internal Control Deficiencies Prior to SOX-Mandated Audits, Journal of Accounting and Economics, 44, 166-192.

Aue, F. and M. Kalkbrener (2007) LDA at Work: Deutsche Bank's Approach to Quantifying Operational Risk, Journal of Operational Risk, 1 (Winter), 49-93.

BCBS (1998) Operational Risk Management, Basel: Bank for International Settlements.

BCBS (2004) Basel II: International Convergence of Capital Measurement and Capital Standards: A Revised Framework, Basel: Bank for International Settlements.

Bebchuck, L.A. (1994) Efficient and Inefficient Sales of Corporate Control, Quarterly Journal of Economics, 109, 957-993.

Bertrand, M., and Mullainathan, S. (2003) Enjoying the Quiet Life? Corporate Governance and Managerial Preferences, Journal of Political Economy, 111, $1043-1075$. 
Brown, S., Goetzmann, W. Liang, B. and Schwarz, C. (2008) Mandatory Disclosure and Operational Risk: Evidence from Hedge Fund Registration, Journal of Finance, 63, 2785-2815.

Burkart, M.C. and Lee, S. (2007) The One Share - One Vote Debate: A Theoretical Perspective, ECGI Finance Working Paper No. 176/2007. http://ssrn.com/ abstract $=987486$.

Burns, N., and Kedia, S. (2006) The Impact of Performance-Based Compensation on Misreporting, Journal of Financial Economics, 79, 35-67.

Chernobai, A., Jorion, P. and Yu, F. (2011) The Determinants of Operational Risk in U.S. Financial Institutions, Journal of Financial and Quantitative Analysis, 46, $1683-1725$.

Davidson, R. and MacKinnon, J.G. (1981) Several Tests for Models Specification in the Presence of Alternative Hypotheses, Econometrica, 49, 781-793.

De Fontnouvelle, P. (2007) Assessing the Financial Industry's Operational Loss Experience: Interesting Findings and Some Open Questions.http://www.prmia. org/Chapter_Pages/Data/Files/1680_2425_Patrick\%20de\%20Fontnouvelle_pre sentation.pdf.

Dechow, P.M., Sloan, R.G. and Sweeney, A.P. (1996) Causes and Consequences of Earnings Manipulation: An Analysis of Firms Subject to Enforcement Actions by the SEC, Contemporary Accounting Research, 13, 1-36.

Doyle, J., Ge, W. and McVay, S. (2007) Determinants of Weaknesses in Internal Control over Financial Reporting, Journal of Accounting and Economics, 44, $193-223$. 
Dutta, K. and Perry, J. (2007) A Tale of Tails: An Empirical Analysis of Loss Distribution Models for Estimating Operational Risk Capital, Federal Reserve Bank of Boston, Working Paper No 06-13.

Efendi, J., Srivastava, A. and Swanson, E.P. (2007) Why Do Corporate Managers Misstate Financial Statements? The Role of Option Compensation and Other Factors. Journal of Financial Economics, 85, 667-708.

Elbannan, M.A. (2009) Quality of Internal Control over Financial Reporting, Corporate Governance, and Credit Ratings, International Journal of Disclosure and Governance, 6, 127-149.

Fisher, G.R. and McAleer, M. (1981) Alternative Procedures and Associated Tests of Significance for Non-Nested Hypotheses, Journal of Econometrics, 16, 103119.

Godfrey, L.G. and Pesaran, M.H. (1983) Tests of Non-Nested Regression Models: Small Sample Adjustments and Monte Carlo Evidence, Journal of Econometrics, 21, 133-154.

Gompers, P., Ishii, J.Y. and Metrick, A. (2003) Corporate Governance and Equity Prices, Quarterly Journal of Economics, 118, 107-155.

Gromb, D. (1993) Is One Share/One Vote Optimal?, Working Paper, London School of Economics. http://denis.gromb.pagesperso-orange.fr/files/1s1v.PDF.

Grossman, S.J. and Hart, O. (1988) One Share-One Vote and the Market for Corporate Control, Journal of Financial Economics, 20, 175-202.

Harris, M. and Raviv, A. (1988) Corporate Governance: Voting Rights and Majority Rules, Journal of Financial Economics, 20, 203-235. 
Jensen, M.C. and Meckling, W.H. (1976) Theory of the Firm: Managerial Behavior, Agency Costs and Ownership Structure, Journal of Financial Economics, 3, 305-360.

Jobst, A.A. (2007) The Treatment of Operational Risk under the New Basel Framework: Critical Issues, Journal of Banking Regulation, 8, 316-352.

John, K., Litov, L. and Yeung, B. (2008) Corporate Governance and Risk-Taking, Journal of Finance, 63, 1679-1728.

Johnson, S., Boone, P., Breach, A. and Friedman, E. (2000) Corporate Governance in the Asian Financial Crisis, 1997-98, Journal of Financial Economics, 58, 141186.

Kaufmann, D., Kraay, A. and Mastruzzi, M. (2010) The Worldwide Government Indicators: Methodology and Analytical Issues, Policy Research Working Papers, World Bank, No 5430, September.

La Porta, R., Lopez-de-Silanes, F., Shleifer, A. and Vishny, R.W. (1998) Law and Finance, Journal of Political Economy, 106, 1113-1155.

Laeven, L. and Levine, R. (2009) Bank Governance, Regulation and Risk Taking, Journal of Financial Economics, 93, 259-275.

Mizon, G.E. and Richard, J.F. (1986) The Encompassing Principle and its Application to Non-Nested Hypotheses, Econometrica, 54, 657-678.

Moosa, I.A. (2007) Operational Risk Management, London: Palgrave.

Moosa, I.A. (2011) Operational Risk as a Function of the State of the Economy, Economic Modelling, 28, 2137-2142.

Moosa, I.A. and Li, L. (2012a) An Operational Risk Profile: The Experience of British Firms, Applied Economics, forthcoming.

Moosa, I.A. and Li, L. (2012b) The Frequency and Severity of Operational Losses: A Cross-Country Comparison, Applied Economics Letters, forthcoming. 
Moosa, I.A. and Silvapulle, P. (2012) An Empirical Analysis of the Operational Losses of Australian Banks, Accounting and Finance, 52, 165-185.

Morrison, A.D. (2004) Sarbanes Oxley, Corporate Governance and Operational Risk, Stockholm Sarbanes-Oxford Seminar, 22 July. www.prmia.org/pdf/Morrison_ SOX_July_2004.pdf.

Murphy, D.L., Shrieves, R.E. and Tibbs, S. (2004) Determinants of the Stock Price Reaction to Allegations of Corporate Misconduct: Earnings, Risk, and Firm Size Effects, Working Paper (University Of Tennessee, Knoxville).

OECD (2005) Definition of Corporate Governance, Glossary of Statistical Terms. http://stats.oecd.org/glossary/detail.asp?ID=6778.

Pesaran, M.H. (1974) On the General Problem of Model Selection, Review of Economic Studies, 41, 153-171.

Pesaran, M.H. and Pesaran, B. (1997) Working with Microfit 4.0: Interactive Econometric Analysis, Oxford: Oxford University Press.

Rodrik, D. (2001) The Global Governance of Trade: As if Trade Really Mattered, Working Paper, Harvard University, John F. Kennedy School of Government Sapovadia, V.K. (2008) Operational Risks in Context to Corporate Governance Practices in India. http://ssrn.com/abstract=1142422.

Shih, J., A. Samad-Khan and P. Medapa (2000) Is The Size of an Operational Loss Related To Firm Size? Operational Risk, January, 1.

Shleifer, A. and Vishny, R.W. (1986) Large Shareholders and Corporate Control, Journal of Political Economy, 94, 461-488.

Shleifer, A. and Vishny, R.W. (1997) A Survey of Corporate Governance, Journal of Finance, 52, 737-788. 
The Economist (2011) Where Angels Fear to Trade, Special Report on International Banking, 14 May, 13-16.

Thirlwell, J. (2004) Operational Risk and Corporate Governance, Operational Risk Research Forum, London, 24 November. www.johnthirlwell.co.uk/oprisk 241104.pdf.

Thirlwell, J. (2011) Operational Risk: Cinderella or Prince Charming?, Monthly Magazine of the Chartered Banker Institute, March 2011. http://finance. flemingeurope.com/operational-risk/operational-risk-cinderella-or-princecharming/.

Vinella, P. (2005) Integrating Corporate Governance and Operational Risk Management, The 2005 PVA International Enterprise Risk Management Symposium, Sheraton Chicago Hotel, 3 May. http://www.ermsymposium.org/ 2005/erm2005/D5_bk.pdf.

Wei, R. (2007) Quantification of Operational Losses Using Firm-Specific Information and External Databases, Journal of Operational Risk 1 (Winter), 3-34.

Young, J. (2006) Operational Risk Management: The Practical Application of a Qualitative Approach, Pretoria: Van Schaik Publishers. 
Figure 1: Average Loss Severity (\$ million)
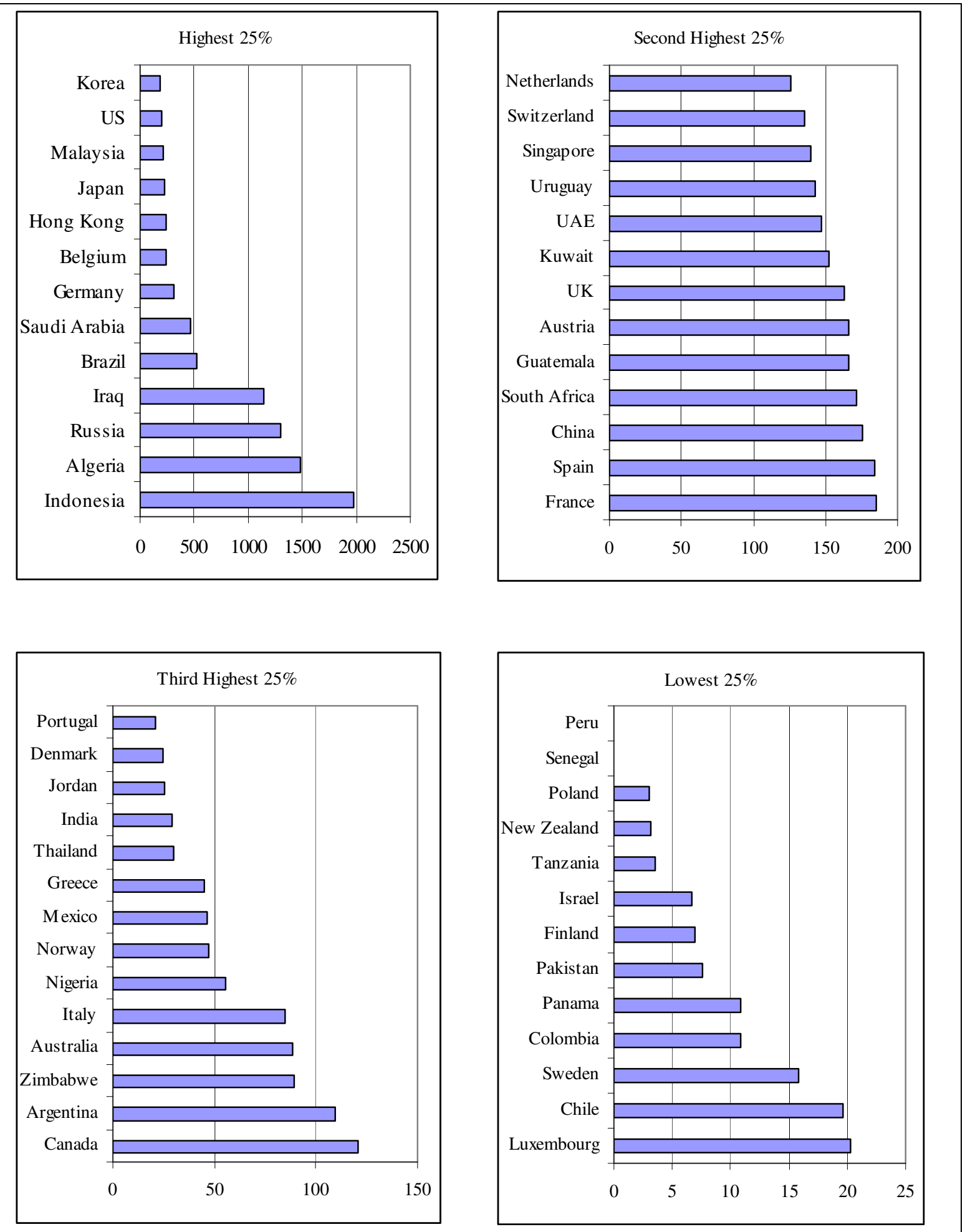
Figure 2: Average Loss Severity by Event Type*

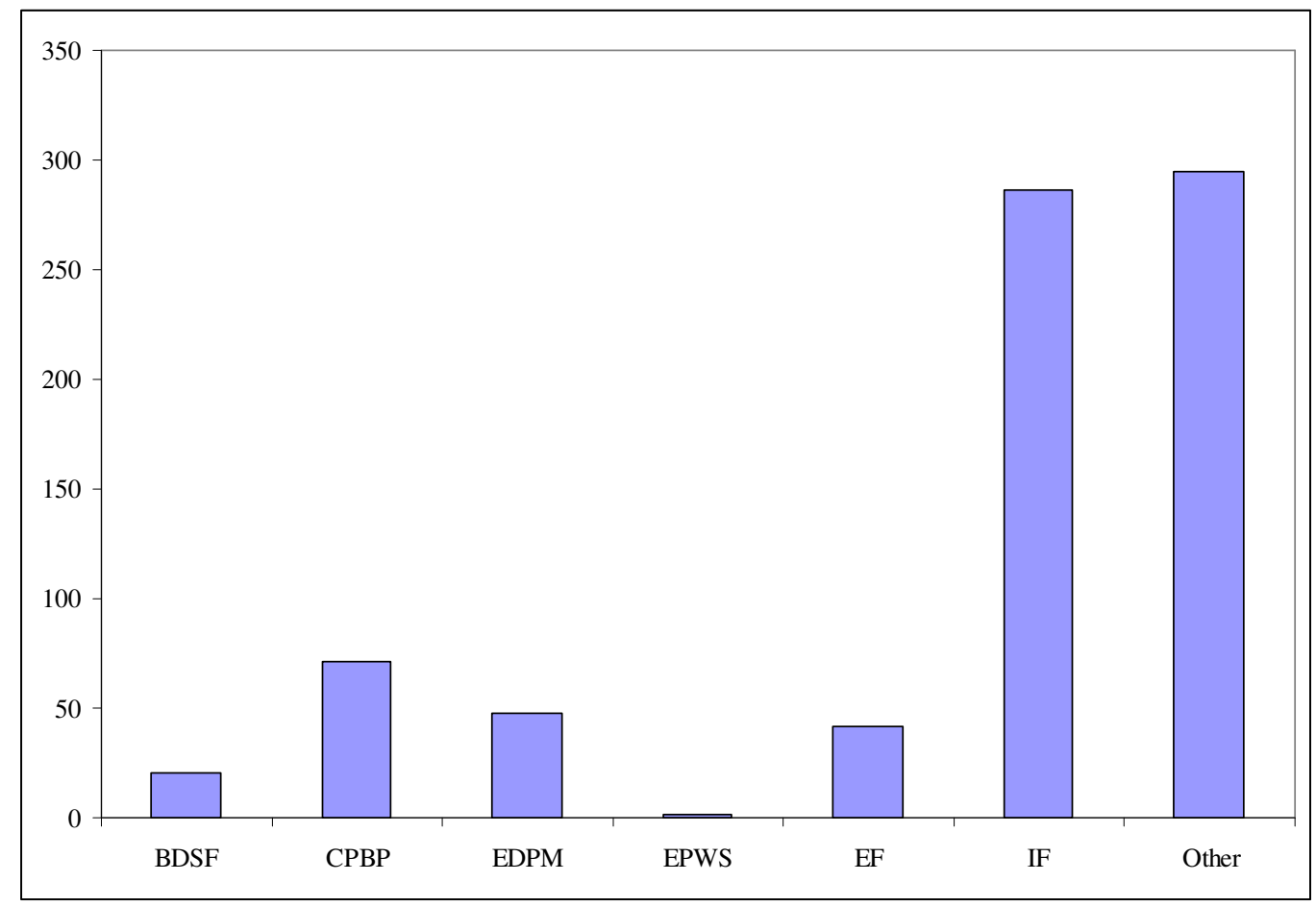

* See appendix for a description of loss events. 
Table 1: Governance Indicators and Examples of Related Loss Events

\begin{tabular}{|c|c|c|}
\hline Governance Indicator & Definition & $\begin{array}{l}\text { Examples of Related } \\
\text { Loss Events }\end{array}$ \\
\hline $\begin{array}{l}\text { Voice and } \\
\text { Accountability }(V O A)\end{array}$ & $\begin{array}{l}\text { Reflects perceptions of the extent to which } \\
\text { a country's citizens are able to participate } \\
\text { in selecting their government, as well as } \\
\text { freedom of expression, freedom of } \\
\text { association, and a free media. }\end{array}$ & $\begin{array}{l}\text { Discrimination, } \\
\text { compensation and } \\
\text { termination issues, } \\
\text { product defects }\end{array}$ \\
\hline $\begin{array}{l}\text { Political Stability and } \\
\text { Absence of } \\
\text { Violence/Terrorism } \\
\text { (POS) }\end{array}$ & $\begin{array}{l}\text { Reflects perceptions of the likelihood that } \\
\text { the government will be destabilized or } \\
\text { overthrown by unconstitutional or violent } \\
\text { means, including politically-motivated } \\
\text { violence and terrorism. }\end{array}$ & $\begin{array}{l}\text { Damage to physical } \\
\text { assets resulting from } \\
\text { terrorism, civil unrest } \\
\text { and vandalism }\end{array}$ \\
\hline $\begin{array}{l}\text { Government } \\
\text { Effectiveness }(G O E)\end{array}$ & $\begin{array}{l}\text { Reflects perceptions of the quality of } \\
\text { public services, the quality of the civil } \\
\text { service and the degree of its independence } \\
\text { from political pressures, the quality of } \\
\text { policy formulation and implementation, } \\
\text { and the credibility of the government's } \\
\text { commitment to such policies. }\end{array}$ & $\begin{array}{l}\text { Missing and incomplete } \\
\text { legal documents, } \\
\text { business disruption and } \\
\text { system failure }\end{array}$ \\
\hline $\begin{array}{l}\text { Regulatory Quality } \\
(R E Q)\end{array}$ & $\begin{array}{l}\text { Reflects perceptions of the ability of the } \\
\text { government to formulate and implement } \\
\text { sound policies and regulations that permit } \\
\text { and promote private sector development. }\end{array}$ & $\begin{array}{l}\text { Insider trading, } \\
\text { compliance with } \\
\text { environmental and } \\
\text { financial regulation, anti- } \\
\text { monopoly rules and } \\
\text { regulations, market } \\
\text { manipulation }\end{array}$ \\
\hline Rule of Law $(R O L)$ & $\begin{array}{l}\text { Reflects perceptions of the extent to which } \\
\text { agents have confidence in and abide by the } \\
\text { rules of society, and in particular the } \\
\text { quality of contract enforcement, property } \\
\text { rights, the police, and the courts, as well as } \\
\text { the likelihood of crime and violence. }\end{array}$ & $\begin{array}{l}\text { internal fraud, external } \\
\text { fraud, discrimination, } \\
\text { health and safety laws, } \\
\text { tax non-compliance, } \\
\text { computer hacking, } \\
\text { forgery, money } \\
\text { laundering }\end{array}$ \\
\hline $\begin{array}{l}\text { Control of Corruption } \\
(C O C)\end{array}$ & $\begin{array}{l}\text { Reflects perceptions of the extent to which } \\
\text { public power is exercised for private gain, } \\
\text { including both petty and grand forms of } \\
\text { corruption, as well as "capture" of the state } \\
\text { by elites and private interests. }\end{array}$ & $\begin{array}{l}\text { Bribes and kickbacks, } \\
\text { credit fraud, } \\
\text { embezzlement }\end{array}$ \\
\hline
\end{tabular}


Table 2: Correlation Matrix of Governance Indicators

\begin{tabular}{|ccccccc|}
\hline & $V A C$ & $P O S$ & $G O E$ & $R E Q$ & ROL & COC \\
\hline VAC & 1.00 & & & & & \\
POS & 0.77 & 1.00 & & & & \\
GOE & 0.84 & 0.87 & 1.00 & & & \\
REQ & 0.83 & 0.85 & 0.96 & 1.00 & & \\
ROL & 0.83 & 0.89 & 0.97 & 0.95 & 1.00 & \\
COC & 0.82 & 0.88 & 0.97 & 0.95 & 0.97 & 1.00 \\
\hline
\end{tabular}


Table 3: Estimation Results of Equation (2)

\begin{tabular}{|ccccc|}
\hline & $\begin{array}{c}\text { Estimated } \\
\text { Value }\end{array}$ & Standard Error & t Statistic & p Value \\
\hline$\alpha$ & -13.269 & 5.98 & -2.22 & 0.033 \\
$G D P$ & 0.437 & 0.203 & 2.15 & 0.027 \\
$G N I$ & 1.353 & 0.537 & 2.52 & 0.016 \\
$A G O V$ & -0.325 & 0.133 & -2.44 & 0.020 \\
$L E S_{1}$ & -0.254 & 1.015 & -0.25 & 0.803 \\
$L E S_{2}$ & 0.844 & 1.100 & 0.77 & 0.448 \\
$L E S_{3}$ & -0.507 & 1.252 & -0.41 & 0.688 \\
$R E G_{1}$ & 2.111 & 2.876 & 0.73 & 0.468 \\
$R E G_{2}$ & 1.761 & 2.945 & 0.60 & 0.554 \\
$R E G_{3}$ & 0.117 & 3.342 & 0.04 & 0.972 \\
$R E G_{4}$ & 1.945 & 2.467 & 0.79 & 0.436 \\
$R E G_{5}$ & 0.778 & 2.472 & 0.31 & 0.755 \\
$R E G_{6}$ & -0.936 & 3.184 & -0.29 & 0.770 \\
$R E G_{7}$ & 0.392 & 2.744 & 0.14 & 0.887 \\
$R E G_{8}$ & 0.925 & 2.710 & 0.34 & 0.735 \\
$R E G_{9}$ & 0.017 & 2.708 & 0.01 & 0.995 \\
$R E G_{10}$ & 1.367 & 2.904 & 0.47 & 0.641 \\
& & & & \\
$R^{2}$ & 0.38 & & & \\
$\mathbb{R}^{2}$ & 0.12 & & & \\
\hline & 1.43 & & & \\
\hline
\end{tabular}


Table 4: Results of Variable Deletion Test

\begin{tabular}{|l|c|c|c|}
\hline \multicolumn{1}{|c|}{ Restrictions } & F Statistic & $\begin{array}{c}\text { Degrees of } \\
\text { Freedom }\end{array}$ & P value \\
\hline$\delta_{j}=0$ for $j=1,2,3$ & 0.38 & $(3,36)$ & 0.766 \\
\hline$\phi_{j}=0$ for $j=1,2, \ldots 10$ & 0.43 & $(10,36)$ & 0.923 \\
\hline $\begin{array}{l}\delta_{j}=0 \text { for } j=1,2,3 \\
\phi_{j}=0 \text { for } j=1,2, \ldots 10\end{array}$ & 0.46 & $(13,36)$ & 0.934 \\
\hline
\end{tabular}


Table 5: Results of Estimating Equation (5)

\begin{tabular}{|c|c|c|c|c|c|c|}
\hline & 1 & 2 & 3 & 4 & 5 & 6 \\
\hline$\alpha$ & $\begin{array}{l}-7.071 \\
(-2.77)\end{array}$ & $\begin{array}{l}-5.371 \\
(-1.80)\end{array}$ & $\begin{array}{l}-8.098 \\
(-2.57)\end{array}$ & $\begin{array}{c}-10.476 \\
(-3.57)\end{array}$ & $\begin{array}{l}-8.215 \\
(-2.63)\end{array}$ & $\begin{array}{l}-7.456 \\
(-2.45)\end{array}$ \\
\hline$G D P$ & $\begin{array}{l}0.559 \\
(3.10)\end{array}$ & $\begin{array}{l}0.448 \\
(2.27)\end{array}$ & $\begin{array}{l}0.544 \\
(2.92)\end{array}$ & $\begin{array}{l}0.542 \\
(3.12)\end{array}$ & $\begin{array}{l}0.512 \\
(2.76)\end{array}$ & $\begin{array}{l}0.452 \\
(2.40)\end{array}$ \\
\hline GNI & $\begin{array}{l}0.531 \\
(2.14)\end{array}$ & $\begin{array}{l}0.446 \\
(2.29)\end{array}$ & $\begin{array}{l}0.702 \\
(2.09)\end{array}$ & $\begin{array}{l}1.0169 \\
(3.18)\end{array}$ & $\begin{array}{l}0.742 \\
(2.18)\end{array}$ & $\begin{array}{l}0.743 \\
(2.06)\end{array}$ \\
\hline$V O A$ & $\begin{array}{l}-1.161 \\
(-3.25)\end{array}$ & & & & & \\
\hline POS & & $\begin{array}{l}-0.701 \\
(-1.51)\end{array}$ & & & & \\
\hline$G O E$ & & & $\begin{array}{l}-1.212 \\
(-2.49)\end{array}$ & & & \\
\hline$R E Q$ & & & & $\begin{array}{l}-1.876 \\
(-3.81)\end{array}$ & & \\
\hline$R O L$ & & & & & $\begin{array}{l}-1.180 \\
(-2.58)\end{array}$ & \\
\hline$C O C$ & & & & & & $\begin{array}{l}-1.039 \\
(-2.39)\end{array}$ \\
\hline$R^{2}$ & 0.30 & 0.19 & 0.24 & 0.35 & 0.25 & 0.23 \\
\hline $\bar{R}^{2}$ & 0.26 & 0.13 & 0.20 & 0.31 & 0.21 & 0.19 \\
\hline $\mathrm{F}(3,49)$ & 7.06 & 3.81 & 5.36 & 8.63 & 5.54 & 5.15 \\
\hline
\end{tabular}


Table 6: Results of Non-Nested Model Selection Tests

\begin{tabular}{|c|c|c|c|c|c|c|}
\hline & $V O A$ & $P O S$ & $G O E$ & $R E Q$ & $R O L$ & $C O C$ \\
\hline \multicolumn{7}{|c|}{ Against $P O S$} \\
\hline \multicolumn{7}{|c|}{$\overline{\mathrm{M} 1 \text { vs M2 }}$} \\
\hline$N$ & -6.87 & & -3.55 & -9.06 & -3.71 & -3.28 \\
\hline$N T$ & -4.33 & & -2.26 & -5.94 & -2.44 & -2.03 \\
\hline$W$ & -3.99 & & -2.16 & -5.31 & -2.33 & -1.95 \\
\hline$J$ & 2.79 & & 1.92 & 3.46 & 2.04 & 1.78 \\
\hline$J A$ & 2.79 & & 1.92 & 3.46 & 2.04 & 1.78 \\
\hline$E N$ & 7.80 & & 3.69 & 11.98 & 4.18 & 3.20 \\
\hline \multicolumn{7}{|c|}{$\underline{\text { M2 vs M1 }}$} \\
\hline$N$ & 0.20 & & 0.05 & 0.57 & 0.24 & -0.09 \\
\hline$N T$ & 0.38 & & 0.25 & 0.68 & 0.39 & 0.15 \\
\hline$W$ & 0.39 & & 0.25 & 0.70 & 0.40 & 0.15 \\
\hline$J$ & -0.20 & & -0.05 & -0.63 & -0.24 & 0.08 \\
\hline$J A$ & -0.20 & & -0.05 & -0.63 & -0.24 & 0.08 \\
\hline$E N$ & 0.04 & & 0.02 & 0.40 & 0.06 & 0.01 \\
\hline \multicolumn{7}{|c|}{ Against } \\
\hline \multicolumn{7}{|c|}{$\overline{R E Q}$} \\
\hline \multicolumn{7}{|c|}{ M1 vs M2 } \\
\hline$N$ & -1.38 & 0.57 & 1.23 & & 0.65 & 1.07 \\
\hline$N T$ & -1.07 & 0.68 & 1.21 & & 0.69 & 1.07 \\
\hline$W$ & -1.03 & 0.70 & 1.26 & & 0.71 & 1.10 \\
\hline$J$ & 1.06 & -0.63 & -1.37 & & -0.68 & -1.18 \\
\hline$J A$ & 1.06 & -0.63 & -1.37 & & -0.68 & -1.18 \\
\hline$E N$ & 1.14 & 0.40 & 1.90 & & 0.46 & 1.39 \\
\hline \multicolumn{7}{|c|}{ M2 vs M1 } \\
\hline$N$ & -3.10 & -9.06 & -4.21 & & -3.85 & -4.45 \\
\hline$N T$ & -2.59 & -5.94 & -3.60 & & -3.26 & -3.74 \\
\hline$W$ & -2.39 & -5.31 & -3.32 & & -3.01 & -3.43 \\
\hline$J$ & 2.10 & 3.46 & 3.07 & & 2.71 & 3.06 \\
\hline$J A$ & 2.10 & 3.46 & 3.07 & & 2.71 & 3.06 \\
\hline$E N$ & 4.44 & 11.98 & 9.43 & & 7.32 & 9.40 \\
\hline
\end{tabular}

All test statistics have t distribution except the $E N$ test statistic, which has an $\mathrm{F}(1,48)$ distribution. 
Table 7: Results of Estimating Equation (9)

\begin{tabular}{|c|c|c|c|c|c|c|}
\hline & 1 & 2 & 3 & 4 & 5 & 6 \\
\hline$\alpha$ & $\begin{array}{l}-5.435 \\
(-1.90)\end{array}$ & $\begin{array}{l}-4.524 \\
(-1.41)\end{array}$ & $\begin{array}{l}-6.451 \\
(-1.97)\end{array}$ & $\begin{array}{l}-8.295 \\
(-2.63)\end{array}$ & $\begin{array}{l}-6.429 \\
(-1.95)\end{array}$ & $\begin{array}{l}-5.559 \\
(-1.76)\end{array}$ \\
\hline$G D P$ & $\begin{array}{l}0.363 \\
(1.91)\end{array}$ & $\begin{array}{l}0.293 \\
(1.89)\end{array}$ & $\begin{array}{l}0.257 \\
(1.96)\end{array}$ & $\begin{array}{l}0.262 \\
(2.10)\end{array}$ & $\begin{array}{l}0.297 \\
(1.98)\end{array}$ & $\begin{array}{l}0.175 \\
(1.94)\end{array}$ \\
\hline GNI & $\begin{array}{l}0.482 \\
(1.97)\end{array}$ & $\begin{array}{l}0.451 \\
(1.95)\end{array}$ & $\begin{array}{c}0.743 \\
(1.98)\end{array}$ & $\begin{array}{l}0.976 \\
(2.81)\end{array}$ & $\begin{array}{l}0.694 \\
(1.92)\end{array}$ & $\begin{array}{c}0.751 \\
(1.96)\end{array}$ \\
\hline$V O A$ & $\begin{array}{l}-1.041 \\
(-2.76)\end{array}$ & & & & & \\
\hline$P O S$ & & $\begin{array}{l}-0.663 \\
(-1.36)\end{array}$ & & & & \\
\hline$G O E$ & & & $\begin{array}{l}-1.292 \\
(-2.21)\end{array}$ & & & \\
\hline$R E Q$ & & & & $\begin{array}{l}-1.875 \\
(-3.24)\end{array}$ & & \\
\hline$R O L$ & & & & & $\begin{array}{l}-1.086 \\
(-2.16)\end{array}$ & \\
\hline$C O C$ & & & & & & $\begin{array}{l}-1.058 \\
(-2.02)\end{array}$ \\
\hline$L O E_{1}$ & $\begin{array}{l}-0.048 \\
(-0.07)\end{array}$ & $\begin{array}{l}-0.255 \\
(-0.35)\end{array}$ & $\begin{array}{l}0.177 \\
(0.24)\end{array}$ & $\begin{array}{l}0.272 \\
(0.40)\end{array}$ & $\begin{array}{l}0.175 \\
(0.24)\end{array}$ & $\begin{array}{l}0.234 \\
(0.31)\end{array}$ \\
\hline$L O E_{2}$ & $\begin{array}{l}-0.634 \\
(-0.85)\end{array}$ & $\begin{array}{l}-0.965 \\
(-1.24)\end{array}$ & $\begin{array}{l}-0.335 \\
(-0.41)\end{array}$ & $\begin{array}{l}-0.008 \\
(-0.01)\end{array}$ & $\begin{array}{l}-0.659 \\
(-0.85)\end{array}$ & $\begin{array}{l}-0.562 \\
(-0.71)\end{array}$ \\
\hline $\mathrm{LOE}_{3}$ & $\begin{array}{l}0.239 \\
(0.34)\end{array}$ & $\begin{array}{l}0.453 \\
(0.58)\end{array}$ & $\begin{array}{c}0.412 \\
(0.56)\end{array}$ & $\begin{array}{c}0.0525 \\
(0.08)\end{array}$ & $\begin{array}{l}0.230 \\
(0.31)\end{array}$ & $\begin{array}{c}0.339 \\
(0.46)\end{array}$ \\
\hline $\mathrm{LOE}_{4}$ & $\begin{array}{l}-0.140 \\
(-0.18)\end{array}$ & $\begin{array}{c}-0.376 \\
(-0.47)\end{array}$ & $\begin{array}{l}-0.255 \\
(-0.33)\end{array}$ & $\begin{array}{l}0.093 \\
(0.12)\end{array}$ & $\begin{array}{l}-0.251 \\
(-0.32)\end{array}$ & $\begin{array}{l}-0.075 \\
(-0.09)\end{array}$ \\
\hline$L O E_{5}$ & $\begin{array}{l}0.283 \\
(0.44)\end{array}$ & $\begin{array}{l}0.287 \\
(0.42)\end{array}$ & $\begin{array}{l}0.387 \\
(0.58)\end{array}$ & $\begin{array}{l}0.324 \\
(0.52)\end{array}$ & $\begin{array}{l}0.291 \\
(0.44)\end{array}$ & $\begin{array}{l}0.339 \\
(0.50)\end{array}$ \\
\hline$L O E_{6}$ & $\begin{array}{l}1.718 \\
(2.14)\end{array}$ & $\begin{array}{l}1.857 \\
(2.18)\end{array}$ & $\begin{array}{l}1.817 \\
(2.21)\end{array}$ & $\begin{array}{l}1.619 \\
(2.07)\end{array}$ & $\begin{array}{l}1.798 \\
(2.18)\end{array}$ & $\begin{array}{l}1.813 \\
(2.18)\end{array}$ \\
\hline$R^{2}$ & 0.39 & 0.31 & 0.36 & 0.42 & 0.36 & 0.36 \\
\hline $\bar{R}^{2}$ & 0.26 & 0.17 & 0.22 & 0.31 & 0.22 & 0.21 \\
\hline $\mathrm{F}(9,43)$ & 3.09 & 2.19 & 2.66 & 3.54 & 2.63 & 2.54 \\
\hline
\end{tabular}

